\title{
THE VIEWS OF COMMERCE STUDENTS REGARDING "FREE" HIGHER EDUCATION IN SOUTH AFRICA
}

\author{
E. Bitzer* \\ Centre for Higher and Adult Education \\ e-mail: emb2@sun.ac.za
}

\section{E. de Jager*}

School of Accountancy

e-mail: edejager@sun.ac.za

*Stellenbosch University

Stellenbosch, South Africa

\section{ABSTRACT}

At the end of 2015, student protests (demanding "free" higher education) took place at most South African universities. In the meantime, a zero per cent increase in university fees for 2016, an increase of not more than 8 per cent for 2017 was announced and by the end of 2017 fully subsided higher education for students from poor and low-income families was granted. South Africa is known for expensive higher education as tuition fees increase every year. Many students struggle to fund their studies, while government subsidies to higher education institution decrease. The question that remains is: Will it be feasible for South Africa to implement "free" higher education?

This study aimed to investigate the perceptions of commerce students at one South African university regarding the feasibility of "free" higher education. A questionnaire was used as research instrument which consisted of Likert-scale statements regarding general ideas about "free higher education" as well as open-ended questions asking students about the definition of "free higher education" and the effects on the South African economy.

The results proposed that even though most students were aware of the students' protests regarding "free higher education" that took place, not all of them agreed with it. The respondents realised that it is not feasible for South Africa to implement "free higher education" at this moment in time.

Despite the views of these commerce students, if "free higher education" were considered as a viable option in South Africa, implementation considerations should be examined. These issues will be discussed in a follow-up study.

Keywords: free higher education; feasibility; funding of higher education; affordability of higher education; commerce students; South African economy; fees must fall 


\section{INTRODUCTION}

Student protests about university fees and demands for "free" higher education occurred at most South African universities at the end of 2015. Cloete $(2015,1)$ remarks that "[T]his was the largest and most effective student campaign since post-1994 South Africa”. These protests were mainly seen as a reaction to a statement by the Department of Higher Education and Training (DHET Statement on Transformation in Higher Education), issued on 17 October 2015, which inter alia pointed to issues related to student funding and debt, fee structures, and the National Student Financial Aid Scheme (NSFAS) (Cloete 2015). These and other concerns have become an urgent matter in South Africa after the formal abandonment of the apartheid dispensation (Akoojee and Nkomo 2007).

On 20 October 2015, three days after the DHET statement was released, an array of protests started and operations at most South African universities grinded to a halt (Cloete 2015). The protests and the idea of "free" higher education were mainly driven under the Twitter banner \#FeesMustFall, but also included other institutional concerns, such as decolonising curricula and language of instruction (Teferra 2016). The protests, however, were not confined to university campuses, but also spread to the parliament buildings in Cape Town (Cloete 2015). Protesting students exclaimed that they had been promised free education. This promise was made long ago at South Africa's first non-racial elections in 1994 (Wild and Mbatha 2015; Parker 2015). Protesters demanded the initiation of processes needed for deep and enduring social change (Vally, Motala, Naidoo, Hlatshwayo and Maharajh 2016).

On 23 October 2015, South African president, Jacob Zuma, announced that there would be a zero percent increase in university fees in 2016 (Cloete 2015). Some students were satisfied with this announcement, while others continued protesting (Moerane 2015). This announcement was followed by an announcement in November 2016 that there would be a fee increase cap of 8 per cent for 2017 for all universities (Majozi 2016).

In a separate statement, President Zuma also said that free university education was possible, but could not be implemented overnight (Wild and Mbatha 2015). By contrast, the Minister for Higher Education and Training, Blade Nzimandi, indicated that "free” higher education for all students would not be possible, but should be restricted to students from poor families. He maintained that some students could afford to pay for at least part of their fees (eNCA 2015). Most analysts, as well as the majority of the media, agreed with Nzimandi. However, an analysis done by the South African Institute of Race Relations indicated that "free" higher education for all was possible if the South African government would adjust their spending priorities (Phungo 2015).

As an expert of higher education policy issues, Cloete (2015) argues that "free" higher 
education is not a good idea, because a developing country, like South Africa, cannot afford it. Moreover, Archer, an economist from the University of Cape Town, asserts that "free" higher education would result in a situation where poor members of society would in fact "subsidise" the richer members of society (Cloete 2015). In addition, Anthony Farr, chief executive officer of the Alan Gray Orbis Foundation, fears that if higher education is "free”, its quality will be reduced, owing to lack of student motivation to complete their studies or to perform to required quality criteria (Raborife 2016).

In the meantime, President Zuma has appointed a commission of inquiry to investigate the feasibility of "free" higher education in South Africa, with the objective to answer the key question: Would "free" higher education work in South Africa? (Essop 2016). Ironically, the term “free” presents a misnomer, as higher education can never be totally “free” of cost (Teferra 2016).

Even though the 2015 student protests were seen as one of the most successful campaigns, student protests are not anything new and equally so to post-apartheid South Africa (Davids and Waghid 2016; Langa 2016). For years there has been a long history of routine protests regarding issues such as rising fees, student access and the cost of higher education which occurred since 1994. Later issues related to student protest include language of instruction, decolonizing university curricula and transformational issues. Although many of these protests were taken note of, they were almost never responded to in a holistic and comprehensive way except for addressing the symptoms thereof (Davids and Waghid 2016; Langa 2016).

Against this background, it was decided to test, at a more scientific level, the opinions of students about the issue of "free" higher education. Our project was directed towards commerce students at one South African university with a rich historical background very much grounded in the apartheid agenda and which will be discussed in the methodology section. Our argument was that these students might be in a better position to make judgements on the notion of "free" higher education than students in other fields, as they study issues of cost, expenditure, monetary value, economics, and so forth. This does not insinuate that students in other fields cannot make such judgements. It was only considered to be a good position to start from. The study concerns the opinions of commerce students in 2016, the year during which the \#FeesMustFall campaign continued, after it had started the previous year.

\section{LITERATURE REVIEW}

South Africa is reportedly a country characterised by one of the most diverse higher education systems worldwide (Cloete 2016). While the system has a history of racial, class and gender inequities, this is not unique, as even in the United States of America the university system still 
shows marks of inequality, with historically disadvantaged ethnic groups remaining significantly underrepresented (Zusman 2005). The issue of race as related to student admissions has always been an important factor that contributed to debates around equity and access in higher education studies (Bitzer 2010).

For many years South Africa has had a history of cost sharing higher education. Cost sharing refers to a shift of costs as a burden for the government or taxpayers to being shared with parents and students (Johnstone 2003). Prior to the first democratic elections in South Africa in 1994, higher education policies were problematic (Odhav 2009). The issues of "free" higher education and frequent tuition fee increases have been debated regularly since as early as the 1960s (Langa, Wangenge-Ouma, Jungblut and Cloete 2016). After 1994, black students in particular were demanding “free” higher education (Wangenge-Ouma 2012). As a result, major shifts took place in terms of broadening access to South Africa's higher education system, especially to previously disadvantaged groups of the society (DHET 2012). If access and ethnic representation are seen as indicators for change, South African higher education has undergone significant changes in recent years (Cloete 2016), but from international experience James (2007) holds the opinion that "free" higher education will not improve equity as there is little evidence anywhere in the world that it has widened participation on a grand scale.

However, undergraduate studies at South African universities are expensive for students and their families, mainly due to government underfunding (Cloete 2016). Despite the fact that higher education is unaffordable for many, well-known South African economist, Dawie Roodt, indicates that South Africa is far from reaching the implementation stage of "free" higher education, due to an unstable economy (Moerane 2015). Making quality university education "free" to all students who qualify would impose an immense burden on a slow growing economy (Vally, Motala, Naidoo, Hlatshwayo and Maharajh 2016).

Before further exploring the question of affordability and related issues, it might be useful to explore the term “free" higher education.

\section{Defining free higher education}

Free (from hereon not indicated by inverted commas) higher education implies that, as existing higher education funding mechanisms do not sufficiently address financial barriers to higher education opportunities (Wangenge-Ouma 2012), funding mechanisms should include subsidised tuition fees, accommodation, food, and related costs (Phungo 2015). While some student protests demand free education for the poor, the majority of students are demanding free higher education for all (Langa, Wangenge-Ouma, Jungblut and Cloete 2016; Parker 2015). South Africa’s Deputy Minister of Higher Education, Mduduzi Manana, urged those who can 
afford to pay for their education to do so (SABC news 2016). The main argument is that free higher education would disproportionately benefit the rich when they are able to afford at least a percentage of the fees (Wangenge-Ouma and Cloete 2008).

Moreover, some officials, among them the Minister of Education and Science, argue that higher education is never free; the only question is who will pay (Smolentseva 2015). Free higher education will mostly affect South African tax payers' pockets (Moerane 2015). Some economists see free higher education as just implicitly borrowing public money, which is paid back through progressive income taxes when graduates start working (Vandenberghe 2005). Hence, higher education is not really free.

What also enters the argument is whether free higher education poses as a right or a privilege. This question is addressed next.

\section{Free higher education as right or privilege}

In many instances, protesting students claimed that they merely fought for their rights, one of which is free higher education (Moerane 2015), a claim based on the fact that many countries worldwide are moving towards education as a basic human right (Christie 2010).

In Chile, for instance, attempts towards free higher education was not about increasing access, but rather to realise a question of principle: if higher education is a human right, it should be "free of charge" (De Gayardon and Bernasconi 2016). Acheampong and Kayange (2016) also assume that all education is a human right, which must be provided to all, regardless of socio-economic status.

The Bill of Rights chapter of the South African Constitution states that everyone has the right to:

- $\quad$ basic education, including adult basic education; and

- further education, which the state, through reasonable measures, must make progressively available and accessible (The Library of Congress 2017).

Parker (2015) judges the term "available” here to mean that the higher education system must be able to provide sufficient space for study and that "accessible" means that higher education should be affordable.

The South African Department of Higher Education and Training (DHET) has indicated to the commission currently (2017) investigating the feasibility of free higher education, that higher education should not be considered as a basic right, but rather as a public and private good, not to be funded by government only. The system should preferably continue using a cost 
sharing model (Stuurman 2016), which constitutes a secondary right to be made available and accessible (Parker 2015).

The question of quality is also closely related to free higher education, since anything that is free might not necessarily be judged as of quality - a sensitive issue that is looked into next.

\section{Quality education}

There is a crucial relationship between access to education and the quality thereof. It is of little use when education is regarded as a right, but its quality is poor and failure is imminent.

While South Africa attempts to offer quality higher education, it also aims at reducing and eliminating inequality. Yet, Cloete (2016) suggests that no higher education system in the world has achieved both these outcomes simultaneously. Hence, broadening access to higher education (by making it free) could mean lower retention and completion rates (Bitzer 2010).

Majozi (2016) strongly believes that if the price of a good or service is zero, quality will be compromised. For instance, the quality of public services such as healthcare in South Africa is low, mainly because it is free and the demand exceeds the supply. Those demanding free higher education should realise the implication of an inevitable decrease in quality for similar reasons.

Quality remains one of the most important measures of the effectiveness of any higher education institution (Allen 2005). However, at most public universities where state funding is insufficient, quality higher education is not guaranteed (Bitzer 2010). The position might even become worse when higher education is financed from a low-growth economy and an overpopulated and bureaucratised government dispensation. This brings us to the question whether free higher education within the South African context is indeed affordable.

\section{Affordability of higher education}

Johnstone (2004) has pointed out that higher education in South Africa is expensive; more so for some student groups than for others. While South African universities are quite affordable for affluent students, as well as for very poor, but gifted students who receive financial aid, higher education is not financially accessible for a large "middle” group (Cloete 2015). The recent student protests are a reminder that many school leavers simply cannot afford university fees (Hull 2015) and currently regarded as a rare commodity - only really affordable by the rich and thus contributing to already unacceptable high levels of inequality (Wangenge-Ouma and Cloete 2008).

South African universities have been increasing tuition fees, one of their fastest growing sources of non-government revenue (Ouma 2007), to cover their financial shortfalls (Langa, 
Wangenge-Ouma, Jungblut and Cloete 2016). Over the past few years, tuition fees have increased between 8 per cent and 9 per cent on average every year (Calitz and Fourie 2016). One reason why tuition fees are increasing annually is that all South African universities constantly face increasing demands on their operating costs, which include electricity fees, campus security, maintenance fees, local rates, library subscriptions and IT bills (Bozzoli 2015). Still, students argue that tuition fee increases provides for a barrier to access (WangengeOuma 2012; Wilson-Strydom and Fongwa 2012). Neill (2009) also maintains that, while fee increases have some effect on students from educated families in Africa, they have a larger effect on relatively uneducated middle class families. This view is supported by a Kenyan study where students perceived higher education as primarily accessible to upper-income families (Ngolovoi 2008). Local studies show that only 5 per cent of South African families can comfortably afford higher education. Thus, when state funding decreases and tuition fees continue to increase, low-income and historically underrepresented ethnic groups of students are excluded (Zusman 2005). This implies that students from disadvantaged backgrounds require subsidies or grants in order to access higher education (Phungo 2015; Raborife 2016).

\section{Funding higher education}

South African higher education funding is increasingly facing challenges such as declining state funding, limited diversification of revenue sources, increases in tuition fees and an increasing demand for support for financially constrained students (Wangenge-Ouma and Cloete 2008). Over the past 20 years government subsidy has decreased, tuition fees have increased and third stream income has remained stable (Bozzoli 2015).

Altbach (2015a) believes that those who get the benefit of studying should pay as they would for any other service. This implies that students should eventually be responsible for the costs of their studies. A study by the British Council (2015) showed that parents are still the main sponsors of tuition fees, but increasingly find it difficult as higher education becomes more expensive.

The main providers of funding to universities worldwide are governments who prove more unwilling or unable to provide the resources needed (Altbach 2015a; Smolentseva 2015). Recently, the financing of higher education shifted from the state to individuals (Berger and Kostal 2002) and in this regard South Africa is no exception as state funding of universities has also declined (Wangenge-Ouma and Cloete 2008; Bloch 2015). In real terms, government funding has declined from 49 per cent of the budgets of universities in 2000 generally to 38 per cent in 2014 - a decrease of more than 22 per cent. Another way of looking at the decline in government funding is to consider the subsidy per student rather than the total government share 
of funding. Here the subsidy per student had decreased by almost 25 per cent between 2000 and 2004, while there was an overall decrease of 8.3 per cent from 2000 to 2013 (Makou, Wilkinson and Bhardwaj 2016). It is thus clear that state subsidy has consistently decreased in relation to student numbers over a long period of time in South Africa (Bozzoli 2015).

Decreases in state subsidies bode critical consequences for the supply and demand of public higher education in the long run (Berger and Kostal 2002; Zusman 2005) and although private higher education is on the increase, also in Africa, access is still heavily dependent on student loans and grants (Altbach 2015b). In addition, students also benefit from university trust funds in some cases. In 2011, for instance, R1 billion was spent by South African universities to fund needy students where financial support was channelled to bursaries from trust funds, donor funding and student fee income (Cloete 2015). This implies that nearly 500000 students were financially assisted by universities themselves.

In many parts of the world, universities make use of student loans which are only repayable if and when the graduate is earning above a certain threshold amount (Hull 2015). However, loans to very poor students in developing countries are not very successful, as loan schemes depend on high pass rates and high graduate employment rates. In South Africa this poses a challenge, with low economic growth and high drop-out rates among first generation black students in particular (Cloete 2015) where low-interest government loans, such as the NSFAS scheme, do not cover the full cost of tuition (Altbach 2015a; Hull 2015). Students thus often have to find additional sources of income to sustain themselves.

\section{Financial aid}

In the 1990s national student financial aid schemes became popular in many countries worldwide (Cloete 2015). Such aid in the form of loans cover tuition fees, accommodation, food, books, and travel costs. These loans must be repaid when students complete their studies and find employment. A percentage of the loan may be converted into a bursary, should the student excel academically (Makou, Wilkinson and Bhardwaj 2016). Unfortunately, the success of such schemes has been limited in developing countries (Barr 2004) due to administrative problems, staff problems, loan recovery problems and corruption (Cloete 2015). For instance, in 2006 the recovery rate for the South African NSFAS was 35 per cent, but in 2014 the rate dropped to an all-time low of 3.7 per cent (Makou, Wilkinson and Bhardwaj 2016).

Together with the zero percent increase announcement for 2016, more than R4 billion were made available in the form of NSFAS loans to South African students who were in debt, who have been underfunded over the past three years, or who had to complete their studies (Pilane 2016). What is of concern, however, is the distribution of billions of rands through the 
NSFAS scheme without monitoring its outcomes. Many NSFAS students who failed to graduate did not pay back their loans, started to revolve back into poverty, and are currently even worse off. This clearly calls for a reassessment of the NSFAS system (Cloete 2016).

\section{The South African economy and the higher education budget}

The South African economy has multiple problems, including high unemployment, a weak schooling system and high rates of societal inequality (Acheampong and Kayange 2016; Zusman 2005). Should the South African government only want to spend 1 per cent of the country's gross domestic product (GDP) on higher education, it would amount to R41 billion. However, the budget for higher education was R30 billion for the 2015-16 financial year. Over the last number of years, South Africa's spending on higher education as a percentage of its GDP varied between 0.68 per cent and 0.72 per cent (Cloete 2015). Compared to other countries, South Africa's expenditure is relatively low. For instance, the proportion of GDP spent on higher education in Brazil is 0.95 per cent, for Senegal and Ghana it is 1.4 per cent, for Norway and Finland it is over 2 per cent, and for Cuba it is 4.5 per cent (Cloete 2015). Furthermore, South Africa's funding for higher education as a percentage of its total education funding is a mere 12 per cent. This is low in comparison to other comparable countries where the percentage is around 20 per cent (Bozzoli 2015).

To constitute a sustainable strategy for accessibility to higher education, the South African government need to increase its funding to a more internationally comparative level of 1 per cent of GDP (Cloete 2015). The South African Institute for Race Relations suggests a level of 2.5 per cent of GDP, while the zero percent concession on higher education in 2016 meant that the state and universities had to find additional funding of R2.6 billion in a time when the South African economy is weak (Wild and Mbatha 2015).

As the government remains under much financial pressure and recently faced degradation to junk lending status by international financial grading institutions, it will probably keep failing to properly fund higher education, yet graduates are needed for developing the economy and the country (Bloch 2015). However, the most common argument against free higher education is that public systems can only afford so much (Vally, Motala, Naidoo, Hlatshwayo and Maharajh 2016) and that less corruption and wastage in government spending and the allocation of a decent proportion of the GDP to higher education would lessen the financial burden on parents, families, communities and students (Phungo 2015; Ngolovoi 2008).

\section{The importance of higher education}

One of the main objectives of public higher education systems is to provide broader access to 
students, which could be substantially jeopardised if the financial burden is heavily shifted to individuals (Berger and Kostal 2002). Broad access would allow more potential for genuine social reorganisation, enabling South Africa as a country to address social inequalities (Vally, Motala, Naidoo, Hlatshwayo and Maharajh 2016). In most countries, higher education is seen as an engine of national economic growth and a provider of individual opportunity and prosperity (Johnstone 2003). The benefits of "free" higher education would therefore be social justice (increasing access for the poor) and growth externalities (developing skills shortages) (Wangenga-Ouma 2012).

The argument is often raised that broader access to higher education will make it a popular commodity, with expanded participation of the poor in higher education having many positive effects (Wangenge-Ouma and Cloete 2008). The British Council (2015) also reiterated that, given the severe inequalities in South Africa, higher education should contribute to a more inclusive society with good public values and thus has a significant role to play in the country's economic development. Yet, it was pointed out by Adam Habib (vice chancellor of the University of the Witwatersrand) that out of a cohort of about 1.1 million Grade 1 learners in South Africa, only approximately 30000 ultimately graduate from higher education.

\section{Money matters}

It seems obvious that the South African government's purse is straining but that it can raise additional revenue by either raising taxes or by borrowing more money at high cost (Teferra 2016). The reality is however that South African tax payers are already overburdened (Moerane 2015) and the situation may be aggravated when those who earn an average income effectively contributes to the education of the rich (Cloete 2016). Furthermore, everyone will contribute through some kind of tax, while fewer than half of South Africans will have access to higher education, and thus only a minority might enjoy its advantages (Hull 2015). Financing free higher education through income tax money unfairly imposes a burden on those who choose not to attend higher education (Vandenberghe 2005).

One possible solution would be to call upon the private sector to assist government in funding higher education institutions (Moerane 2015). Some institutions are already requiring that certain academic programs, especially high demand, high return professional programs, such as law or business, become fully funded by businesses or private resources (Zusman 2005).

Hull (2015) argues that to the extent that higher education is an individual good, the individual who benefits from it should pay for it. However, to the extent that it is a public good, the state should pay for it. This ratio ought to be around 50:50. South Africa currently uses a funding structure where university costs are shared and which need to be better refined (Phungo 
2015). According to Johnstone (2004), the principal parties for cost sharing in higher education are (1) the government, or taxpayers; (2) parents; (3) students; and/or (4) individual or institutional donors.

Against this background we decided to ask students from Economic and Business Sciences at one South African university for their views on the nature and feasibility of free higher education. The rationale was that, contrary to students in other fields of study, these students would probably render a more informed view on university fees and the possibility of offering cost-free tuition to students.

\section{METHOD}

\section{Background}

The study was conducted at the Economic and Management Sciences (EMS) faculty at one research intensive South African university. This university had been formally established early in the previous century and related in complex ways to the earlier apartheid dispensation. Before its widened admission policies in the 1980's, the University catered predominantly for white and Afrikaans-medium students, but since the 1990's its admission policies changed substantially to include a wider range of students with a current language policy that promotes multilingualism. In 2016 the number of generic black students enrolled at the University accounted for about 40 per cent of the total number of students across 10 faculties, of which the EMS faculty is the largest. EMS students are perceived to be knowledgeable about general finances and the economy of a country, as all the programmes in this faculty reflect strong financial and managerial approaches to reality.

Learning about student perceptions can be useful, as they are the "customers" of higher education institutions and are considered the lifeblood of an institution's existence. If students' perceptions are better gauged and understood, it might contribute to overall institutional satisfaction (Nell and Cant 2014) and can be used by stakeholder groups (e.g. the government) to make judgements and decisions about higher education issues such as tuition.

\section{Research aim}

Our study aimed at investigating the perceptions of commerce students regarding the feasibility of tuition-free higher education. In addition, the inquiry sought to determine how students define the term "free higher education", and to generate their thoughts on general statements about free higher education. Hence the question: Do commerce students think free higher education will work in South Africa? 
A validated survey questionnaire was electronically distributed to 6004 commerce students at one South African university and students had two weeks to voluntarily complete the questionnaire anonymously online. Ethical clearance and institutional permission were obtained from the relevant university authorities.

\section{Student survey}

The questionnaire consisted of five parts. The first part included general questions pertaining to the background variables of the students. In the second part students were asked to rate general statements regarding free higher education on a 5-point Likert scale, varying from 1 to 5 (where 1 = "completely disagree" and 5 = "completely agree”). In the third part of the questionnaire students were asked questions regarding the costs of their studies, while the fourth part comprised questions on the implications of tuition-free higher education. The last part consisted of a number of open-ended questions, testing students' views on the definition of free higher education and its effects on the South African economy if implemented. In this study only the Likert scale statements and some of the open-ended questions (which support the responses of the Likert scale statements) were analysed. The possibilities for implementing free higher education will be discussed in a follow-up article.

\section{Biographical information of student respondents}

All students enrolled for an EMS course (excluding students at the Business School, Aids Centre, and School of Public Leadership) enrolled in 2016 at the particular university were invited to participate. The EMS faculty presents a variety of undergraduate and postgraduate courses, all with a financial basis. Questionnaires were subsequently emailed to a total of 6004 students and 1201 were returned, representing a 20 per cent response rate. The overall profile of the respondents is summarised in Table 1.

The cohort comprised more or less 50 per cent male and 50 per cent female students. Respondents were a combination of first, second and third year (undergraduate), as well as postgraduate students. The home language of most of the respondents is Afrikaans, while the majority indicated that their language of tuition is English and the majority of the respondents are white.

\section{Analysis}

Frequency analyses were performed on the 1201 closed-ended Likert-scale responses related to the general ideas regarding free higher education. The results of the open-ended questions were analysed by transcribing, coding and categorising its contents according to themes. Quotes 
in the results section of this article represent typical responses received and were selected to support the results and the points raised.

Table 1: Participant profile $(n=1201)^{\star}$

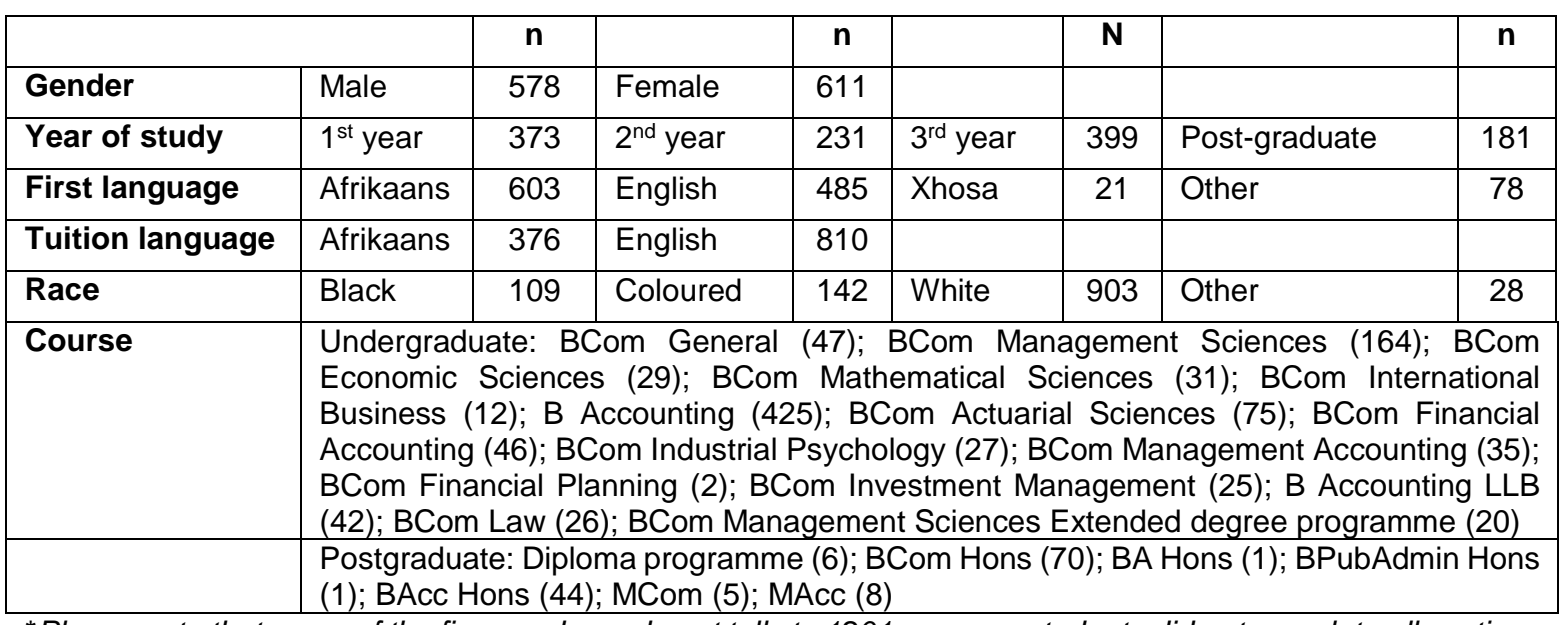

${ }^{*}$ Please note that some of the figures above do not tally to 1201 as some students did not complete all sections of the biographical section of the survey.

\section{FINDINGS AND DISCUSSION}

\section{How students perceive tuition-free higher education}

One open question in the questionnaire asked students what they understood by the general term "free higher education". A variety of responses were received. The main issues that emerged were:
a) Who should receive "free" higher education?
b) Which institutions should offer "free" higher education?
c) What costs should be "free"?
d) Who will settle the bill?

Firstly, most respondents stated that everyone should be granted free higher education. They did not believe that it should be limited to a certain income group, race or educational programme. However, a few students indicated that only "deserving” students should be granted free higher education, referring to hard working, academically successful students who are not able to afford it. A few respondents also added that the admission requirements should still be met by students. The following quotes were typical of the most frequent responses:

"It refers to an ideal that higher or tertiary education is made accessible to all people who wish to learn. Free higher education is fair and is not reserved for a specific age, financial status, race, gender, class, culture, language or nationality.” 
"That all forms of public higher education should not be withheld from any student based on lack of financial aid."

"Free education for me means that the only thing that should stop a potential student from studying should be the admission requirements of whatever course they want to do."

Secondly, the majority of the respondents indicated that free higher education should be applicable to all public higher education institutions and not be limited to particular universities. One typical response read as follows:

"That all universities, colleges and technikons (sic) are free, i.e. students do not have to pay tuition."

Thirdly, the students who indicated free education as a model, mostly focused on tuition fees as the main issue. However, some respondents also indicated that books, accommodation, meals and other expenses should also be free. Some typical comments in this respect included the following:

"[It] includes the tuition to study and books and accessories needed to complete a degree/certificate.”

"All the costs associated with studying after school should be free."

"[A]ny course in higher education ... the tuition ... is for free."

Lastly, a large contingent of students indicated that the funding of free higher education should be provided by either the government or taxpayers. Either way, they agreed that the costs relating to higher education should not be for their own or their family's account. Their thoughts on the funding of free higher education were illustrated by comments such as the following:

"Education funded by someone else; not the student or his/her family (funded by organisations or the government)."

"Free higher education is access to higher education institutions at no cost to the student or his/her family, although the costs will still have to be borne by someone else (government, private sector, etc.).”

\section{Ranking of statements about tuition-free higher education}

Students also had to rate general statements about "free" higher education. The median and mean were calculated (see Table 2). 
Table 2: Student views on tuition-free higher education

\begin{tabular}{|l|c|c|}
\hline & Median & Mean \\
\hline A. I am aware of the protests regarding free higher education & 5 & 4.5 \\
\hline B. I support the protests regarding free higher education & 3 & 2.7 \\
\hline C. I agree with the zero percent fees increase for 2016 & 4 & 3.4 \\
\hline D. I consider financial access to higher education as a right & 3 & 2.9 \\
\hline E. I consider higher education as a privilege & 4 & 4.0 \\
\hline F. I think free higher education is possible in South Africa & 2 & 2.3 \\
\hline G. I think free higher education makes economic sense in South Africa & 2 & 2.2 \\
\hline H. I think the South African government is able to implement free higher education & 2 & 2.2 \\
\hline I. I think higher education institutions have funds to implement free higher education & 2 & 2.1 \\
\hline J. I/my family struggle to pay for my higher education & 3 & 3.1 \\
\hline K. I would benefit from free higher education & 4 & 3.9 \\
\hline L. I think students are realistic about free higher education & 2 & 2.1 \\
\hline M. I think the quality of higher education will remain the same if higher education is free & 2 & 1.9 \\
\hline
\end{tabular}

\section{Awareness and agreement with protests (statement $A$ and $B$ )}

More than 90 per cent of the participating students were aware of the protests regarding free higher education. It was thus important to learn more about their thoughts on the protests and it was clear that mixed views regarding the issue emerged. Only 25 per cent of the students seemed to have fully supported the protests, whereas the rest were either neutral or did not support it. It may be possible that students, at the time of the survey, were not fully aware of or did not understand the motives behind the protests and as a result were uncertain about whether they support it or not.

A corresponding open-ended question asked students to substantiate why they agreed or disagreed with the implementation of free higher education. Students in favour argued that it would be beneficial to the economy of South Africa in terms of growth, and the reduction of poverty and crime. Students also seem to believe that everybody deserves an equal opportunity to study, especially in the face of the fact that many talented, hardworking students do not have the necessary funds. Some even argued that higher education is a societal right and the following quotes demonstrate some of the general views in favour of free higher education:

"I do agree that free higher education should be implemented. It is not fair that people are restricted and unable to reach their full potential simply because of their financial status or any other defining factor such as their age, race, gender, class, culture, language or nationality. To end the cycle of economic inequality and to emerge as a developed/first-world nation, South Africa must at least try to make higher education a right, and not just a privilege for a select few.”

"I agree that free higher education should be implemented in order to further our economy and to brighten the futures of the countries youth."

"I agree that it should be because it allows everyone opportunities to prosper rather than just a 
select few and it would result in better social circumstances such as reduced crime and poverty as well further development of cities' and SA's reputation.”

Students who argued against the implementation of free higher education are convinced that the South African economy is not sufficiently strong for this. They also fear that free higher education would lower standards and quality and that some students might take advantage of the situation by not finishing their studies - the reason being that if something is free, it is taken for granted and not properly valued or utilised. Furthermore, they argue that basic education is more important than higher education, and the former should thus be prioritised. The quotes below reflect some of the general student views against the implementation of free higher education:

"As idealistic as free higher education is, South Africa at the moment is simply not able to afford something as costly and far-reaching as higher education funding.”

"In a country like South Africa, we do not have the resources to implement free higher education. The standard of education would decrease dramatically and South African degrees would not be recognized elsewhere.”

"While I believe that free higher education should be an ultimate goal for the country, I feel that it is not higher education that should be targeted but rather initially primary and secondary education. It will allow a whole new sector of people to be able to get basic education and potentially be able to apply to higher education facilities. Ultimately, primary and secondary education should be targeted first, then higher education.”

\section{Zero per cent tuition increase (statement C)}

A total of 52 per cent of the students agreed with the announced zero percent increase in tuition fees for 2016. The majority reasoned that everybody would want a zero percent increase for any paid service. By contrast, the 48 per cent students who were unsure about or disagreed with the statement were probably considering the consequences, such as institutions experiencing a lack of funds to cover their running costs, the doubling of fees the following year to make up for the loss, and a drop in the quality of education. This corresponds with previous research which indicated that running costs, which increases every year, remains an important part of a university’s budget (Bozzoli 2015) and quality educational offerings (Allen 2005; Majozi 2016) As an example of why a zero percent increase was not a good idea one student responded as follows:

"The economy is already unstable and the University staff already had to forfeit salary increases due to the \#feesmustfall movement with just a zero \% increase (as opposed to free education). Thus, in my opinion, if free education were to be implemented, the lecturers and staff would be underpaid, thus steering them towards private institutions - which means the quality of lecturers 
i.e. education will fall.”

\section{Right or privilege (statement $D$ and $E$ )}

When students were asked whether they had a right to financially access higher education, mixed views emerged. Almost 37 per cent agreed that financial access is a right, while the same percentage disagreed, and 27 per cent were unsure. Some argued that the South African Constitution does not indicate higher education as a primary right (The Library of Congress 2017) and most students (76\%) see higher education a privilege rather than something they are entitled to. This probably relates to the response regarding agreement with the protest: If most students regard higher education a privilege and not a basic human right, it makes sense that the majority also would not necessarily support the protests (also see Singh 2001 on the question of higher education being a privilege). To demonstrate - one respondent had strong views on this issue and commented as follows:

"I believe that education is a privilege, not a right. If one wants to enjoy this privilege, one should pay for it. We cannot all live at the expense of others. If one wants to show value in something, one invests in it, both time and money. If we as South Africans want to prove we value education, we should invest in it, in terms of money."

\section{Possibility and economic sense in South Africa (statement F and G)}

Commerce students seem to have reservations regarding the feasibility of free higher education as only 23 per cent viewed it possible, while only 20 per cent indicated that it makes economic sense. The majority of students view free higher education as not being possible. The following arguments were highlighted in the open responses:
(a) South Africa’s struggling economy
(b) Government corruption
(c) Lack of funds
(d) Poor spending habits of government
(e) South Africa as a $3^{\text {rd }}$ world country

The sample quotes below reflect some of these views:

\footnotetext{
"Because our government cannot set up a proper budget and does not have boundaries when it comes to spending."

"Our current government is riddled with corruption and government officials are remunerated far too generously. If the government were really for the people they would end this injustice and redistribute their wealth to their people in dire need.”
} 
"The government does not have enough available funds to provide such a service and would have to increase taxes which many families cannot afford already."

"SA self is a third-world country that still depends on outside financing to cover cost at the moment."

Yet, a handful of students seemed positive about implementing free higher education. However, they mentioned that it could only be realised if government manages the budget properly, spends less, and addresses corruption. A Kenyan study (Ngolovoi 2008) showed similar responses from students regarding the distrust in government. In our study the more positive responses included statements such as the following:

"Yes, maybe not at this point in time but in the years to come and the correct steps in place and correct funding, hopefully free higher education will exist."

"The South African government can definitely budget for free higher education to students. By combining the budgets for grants to the universities and that of NSFAS, eliminating a large portion of wasteful expenditure each year, and streamlining the public service, the government would be able to fund free higher education to every academically deserving student in South Africa, even if they could afford it.”

\section{Whether government or higher education institutions should provide funds (statement $\boldsymbol{H}$ and $\mathrm{I}$ )}

On the statement that the South African government is able to implement free higher education, the majority (66\%) of student responses were negative. The same response emerged as to whether higher education institutions have the funds to implement free higher education. On these issues commerce students might realise that funding for free higher education is not readily available, that national budget annually struggles to prioritise expenditure, and that higher education institutions themselves do not have additional funds for sustainable student support. In addition, constantly low percentages of the GDP being allocated to higher education shows that the South African government's budget is under much strain (Cloete 2015).

Mixed responses emerged from the open-ended question as to whether it makes economic sense to implement free higher education. Some respondents referred to the fact that the economy will be negatively affected in the short term, while others focused on the future economic benefits, such as a better educated workforce, less unemployment and alleviating poverty. However, the majority of responses emphasised that short term budgetary challenges will be surpassed by long term national benefits. One comment serves to illustrate:

"In the short run we will be dead poor but in the long run we might see an incline in our economy due to more people being able to do professional jobs and contributing to our economy as tax payers.” 


\section{Struggles and benefits (statement $\mathrm{J}$ and $\mathrm{K}$ )}

Just over 50 per cent of commerce students indicated that they or their families struggle to pay for higher education, while almost 25 per cent indicated that they or their families could afford such fees. The remaining 25 per cent were uncertain.

However, 48 per cent of the students indicated that their families sponsored their studies in 2016. The rest indicated that family contributions were supported by merit bursaries, bank loans, NSFAS funding or employer bursaries. More than 60 per cent mentioned that they had applied for some kind of funding (e.g. merit bursary, bank loan, NSFAS) in 2016, but were unsuccessful. While half of the students mentioned struggles regarding funding, 70 per cent said that they would benefit from receiving free higher education. It might thus be assumed that even if students do not struggle with funding, they will benefit as everyone would benefit from a service that is free.

This raises the question whether the 2015/16 student protests were about free higher education for all students or only for those without any financial means (Langa, WangengeOuma, Jungblut and Cloete 2016). From the responses gleaned in this study, it seems clear that students were in disagreement about who the students are who struggle financially and who would really benefit from free higher education. Such differences are demonstrated by statements such as the following:

"Funding and bursaries are only benefiting the rich and those with access to better schools with good grades while the poor get left behind."

"Most of the poor population of South Africa are being targeted already for opportunities to higher education as majority of the bursaries and grants are aimed specifically at the poor - thus they would be benefiting twice as much as, say, a middle class family who are better off but not well off enough to send their children to University. As these children do not fall in the "poor" category, there are no opportunities. For them to get access to bursaries, etc and so they are unable to study as well - but no one is extending a hand to help them."

"It should be implemented fairly across different races and class segments. It cannot be implemented for one group and not the other."

\section{Realism (statement $L$ )}

Almost 70 per cent of the participating commerce students indicated that protesters might not be realistic about free higher education. This resonates with statement $\mathrm{B}$, where only 25 per cent of the respondents agreed with the protests. The open-ended responses also highlighted that protesters were demanding something that might not be realistic within the current economic climate. Some examples: 
“It doesn’t seem plausible in South Africa at the moment. Unrealistic.”

"I do agree that free education should be implemented, however in our current economic situation this could be unrealistic for the next 10 years."

"I don't think it is a possibility/realistic goal for the near future. Too much must first change in our government structure and in the heart and beliefs of our nation before free higher education will be possible or implemented fairly and sustainable."

\section{Quality of higher education (statement M)}

Only 11 per cent of students indicated that the quality of higher education will remain the same if higher education is free. The majority are thus of the view that quality, which can include the quality of learning materials, lecturers' experience and knowledge, teaching, administration, facilities and other elements would be compromised. Bitzer (2010) supports this view by stating that the quality of a public university cannot be guaranteed or promoted without sufficient and sustainable public funding.

It seems that one main reason for disagreement with the free higher education protests is a fear of decreases in educational quality as some students typically responded as follows:

"I do not agree that free higher education should be implemented because it will affect the quality of the university, its infrastructure and its services."

"With insufficient funds, the higher education system will decay and eventually be of no benefit to anyone. The universities (All higher education institutions) will lose their reputations and the employment of people with higher education will decline as companies lose trust in the quality of their qualifications.”

"I also think that the quality of education will decrease and the value of having a degree will not be that valuable anymore.”

\section{CONCLUSIONS AND IMPLICATIONS}

What seems clear is that both current and previous student protests against student fees and the affordability of studies in general show that South Africa still has a complex and unequal higher education system (Aitchinson 2003). However, although free higher education sounds revolutionary and attractive, it presents as financially unattainable and morally unjustifiable within developing societies. There are voices advocating rather for affordable higher education for all (Cloete 2016), which implies differentiated higher education fees for different income groups. Free higher education for all would probably result in a whole nation paying indirectly more for higher education, with the possibility of the poor in effect subsidising the rich (Teferra 2016). In addition, Cloete (2016) warns that burning down university buildings and destroying university property might worsen, rather than solve, the problem of inequality. 
In this study the views of more than a thousand commerce students at one South African university indicated that while most were aware of the 2015-16 \#FeesMustFall protests, not all supported it. The majority seem to view higher education as a privilege rather than a right, even though half of them indicated that they struggle to pay for their university education. The majority of these students are also of the view that the implementation of free higher education for all South African students is not currently feasible, and that neither the government nor higher education institutions themselves have sufficient funding to make this possible. While most students indicated that they would benefit from free higher education, many were concerned about the possible deterioration in quality of higher education and compromising the value of their qualifications. In summary, most of the participant commerce students in this study seem to see the benefits of free higher education in South Africa, but also realise that it may not be currently feasible.

A presidential commission of inquiry was set up in 2016 to make recommendations on the feasibility of free higher education in South Africa (Essop 2016). The commission has to take into account relevant legislation, the South African constitution, the findings of various task teams, as well as education policies and guidelines. Preliminary results were released in September 2016 and Higher Education and Training Minister at the time, Blade Nzimande, announced a maximum tuition fee increase of 8 per cent for 2017, with the government funding fee increments up to 8 per cent for students whose family income is below R600 000 per annum (DHET 2017). The final report of the fees commission was handed over to President Zuma on 30 August 2017 (Kubheka 2017) and on 16 December 2017 he announced fully subsidised higher education for students from poor and working class families with an annual income of up to R 350000.

Despite efforts to find solutions to increasingly expensive higher education and to address inequality, certain groups of students continued their protest actions and demanded immediate solutions (eNCA 2015). Yet, the key question is, if and when free higher education might be possible and implemented, would there be:

- $\quad$ sufficient space at universities to accommodate everyone (Wilson-Strydom and Fongwa 2012);

- $\quad$ an unlocking of higher educational opportunities for the poorly schooled, as they would still need to meet the admission requirements (Wangengi-Ouma 2012; Langa, WengengeOuma, Jungblut and Cloete 2016);

- an over-supply of qualified students who might not find job opportunities amidst a 
constrained economy (Hull 2015); and

- adequate success rates amongst those students receiving free higher education?

What also remains is how relatively poor higher education students can be assisted to be successful. A disturbing statistic is, for instance, that more than 70 per cent of students on the NSAF scheme never complete their studies (Cloete 2016). Another question is whether, in an ideal world, higher education could actually be free. This pertains to whether a "free" higher education system would promote equity and justice, since some are of the view that, although free higher education for all might be feasible, it might cause or contribute to further societal injustices in an already unequal society such as South Africa (Hull 2015).

The \#FeesMustFall upsurge might have been a necessary part of South Africa's history to remind us of immanent and raging inequalities (Davids and Waghid 2016). Yet, informed students and experts alike conclude that free higher education for all is not feasible. Government resources in South Africa are not infinite and amidst other constraining factors such as slow economic growth, corruption and weak leadership higher education is in principle not more important than other essential services (Wangenge-Ouma and Cloete 2008). Ultimately, as our commerce student survey has pointed out, nothing in modern society is without cost and therefore higher education in South Africa would probably not become entirely "free". This being said, this study needs to be replicated in different faculties as well as in different higher education institutions to make its findings more trustworthy and valid for the South African student population and context.

\section{NOTE}

1. The term "free" is indicated in inverted commas as no public service can be considered as "free". All education involves costs and thus there has to be adequate financial provision for such a service.

\section{REFERENCES}

Acheampong, P. and J. J. Kayange. 2016. University education in Ghana: A privilege or a right? International Journal of Research Studies in Education 6(3): 17-25.

Aitchinson, J. 2003. Struggle and compromise: A history of South African adult education from 1960 to 2001. Journal of Education 29: 125-171.

Akoojee, S. and M. Nkomo. 2007. Access and quality in South African higher education: The twin challenges of transformation. South African Journal of Higher Education 21(3): 385-399.

Allen, W. R. 2005. A forward glance in the mirror: Diversity challenged - access, equity and success in higher education. Educational Researcher 34: 18-23.

Altbach, P. G. 2015a. Higher education and the WTO: Globalization run amok. http://ejournals.bc.edu /ojs/index.php/ihe/article/view/6593 (Accessed 12 September 2016). 
Altbach, P. G. 2015b. The costs and benefits of world-class universities. https://ejournals.bc.edu/ ojs/index.php/ihe/article/viewFile/7381/6578 (Accessed 12 September 2016).

Barr, N. 2004. Higher education funding. Oxford Review of Economic Policy 20(2): 264-283.

Berger, M. C. and T. Kostal. 2002. Financial resources, regulation, and enrollment in US public higher education. Economics of Education Review 21(2): 101-110.

Bitzer, E. M. 2010. Some myths on equity and access in higher education. South African Journal of Higher Education 24(2): 298-312.

Bloch, G. 2015. Free education is a worthy goal, but South Africa isn't ready for it yet. http://theconversation.com/free-education-is-a-worthy-goal-but-south-africa-isnt-ready-for-ityet-49414 (Accessed 3 September 2016).

Bozzoli, B. 2015. Behind the university funding crisis. http://www.politicsweb.co.za/news-andanalysis/behind-the-university-funding-crisis (Accessed 3 March 2017).

British Council. 2015. Student perceptions of employability and inclusive development: South Africa. https://www.britishcouncil.org/sites/default/files/2.5_student-perceptions-of-employabilityinclusivity.pdf (Accessed 2 April 2016).

Calitz, E. and J. Fourie. 2016. The historically high cost of tertiary education in South Africa. Stellenbosch Economic Working Papers: 02/16. Stellenbosch: University of Stellenbosch and Bureau of Economic Research.

Christie, P. 2010. The complexity of human rights in global times: The case of the right to education in South Africa. International Journal of Educational Development 30(1): 3-11.

Cloete, N. 2015. The flawed ideology of “free higher education”. http://www.universityworldnews. com/article.php?story=20151104111825416 (Accessed 3 September 2016).

Cloete, N. 2016. Free higher education: Another self-destructive South African Policy. Paper published by the Centre for Higher Education Trust.

Davids, N. and Y. Waghid. 2016. \#FessMustFall: History of South African student protests reflects inequality's grip. https://mg.co.za/article/2016-10-10-feesmustfall-history-of-south-africanstudent-protests-reflects-inequalitys-grip (Accessed 12 January 2017).

De Gayardon, A. and A. Bernasconi. 2016. Chilean Universities: Not so tuition-free after all. http://ejournals.bc.edu/ojs/index.php/ihe/article/view/9372 (Accessed 3 April 2017).

Department of Higher Education and Training. 2012. Report of the working group on fee free university education for the poor in South Africa. Accessed 3 September 2016: http://www.dhet.gov.za/SiteAssets/Fees\%20Must\%20Fall/287700266-Final-Draft-Report-ofthe-Working-Group-on-Fee-Free.pdf

Department of Higher Education and Training. 2017. Release of the Report of Commission of Inquiry into the Feasibility of making Higher Education and Training Fee-free in South Africa. http://www.dhet.gov.za/SiteAssets/Latest\%20News/2017/October\%202017/Release\%20of\% 20the\%20Report\%20of\%20Commission\%20of\%20Inquiry\%20into\%20the\%20Feasibility\%20o f\%20Making\%20High\%20Education\%20and\%20Training.pdf (Accessed 15 November 2017).

DHET see Department of Higher Education and Training.

eNCA. 2015. Nzimande says no money for free tertiary education. http://www.enca.com/southafrica/nzimande-says-no-money-free-tertiary-education (Accessed 3 September 2016).

Essop, R. 2016. Commission of inquiry to look into feasibility of free higher education. http://ewn.co.za/2016/01/14/Zuma-officially-appoints-commission-of-inquiry-for-free-highereducation (Accessed 12 January 2016).

Hull, G. 2015. Free university education is not the route to social justice. http://theconversation.com/ free-university-education-is-not-the-route-to-social-justice-49755 (Accessed 3 September 2016).

James, R. 2007. Social equity in a mass, globalised higher education environment: The unresolved issue of widening access to university. University of Melbourne, Centre for the Study of Higher Education. 18 September 2007. 
Johnstone, D. B. 2003. Cost sharing in higher education: Tuition, financial assistance, and accessibility in a comparative perspective. Sociologický časopis/Czech Sociological Review 39(3): 351-374.

Johnstone, D. B. 2004. The economics and politics of cost sharing in higher education: comparative perspectives. Economics of Education Review 23(4): 403-410.

Kubheka, T. 2017. Zuma receives fees commission report. http://ewn.co.za/2017/08/31/zuma-receivesfees-commission-report (Accessed 6 September 2017).

Langa, M. 2016. \#Hashtag: An analysis of the \#FeesMustFall movement at South African universities. https://www.csvr.org.za/pdf/An-analysis-of-the-FeesMustFall-Movement-at-South-Africanuniversities.pdf (Accessed 6 September 2017).

Langa, P., G. Wangenge-Ouma, J. Jungblut and N. Cloete. 2016. South Africa and the illusion of free higher education. http://www.universityworldnews.com/article.php?story=20160223145336908 (Accessed 14 April 2016).

Majozi, P. 2016. Quality education isn’t free. Expect a fallout, either way. http://www.biznews.com/ thought-leaders/2016/09/28/phumlani-majozi-quality-education-isnt-free-expect-a-fallout-eitherway (Accessed 16 March 2017).

Makou, G., K. Wilkinson and V. Bhardwaj. 2016. Factsheet: Funding and the changing face of SA's public universities. https://africacheck.org/factsheets/factsheet-funding-changing-face-saspublic-universities (Accessed 3 March 2017).

Moerane, B. 2015. SA far from free tertiary education: Economist. http://www.sabc.co.za/ news/a/76b40b004b239e5bbb38fb445cadceaa/SA-far-from-free-tertiary-education:-Economist20153112 (Accessed 3 September 2016).

Neill, C. 2009. Tuition fees and the demand for university places. Economics of Education Review 28(5): 561-570.

Nell, C. E. and M. C. Cant. 2014. Determining student perceptions regarding the most important service features and overall satisfaction with the service quality of a higher education institution. Management: Journal of Contemporary Management Issues 19(2): 63-87.

Ngolovoi, M. S. 2008. Financing higher education in Kenya: Student perceptions and experiences. Tertiary Education and Management 14(2): 141-150.

Odhav, K. 2009. South African post-apartheid Higher Education policy and its marginalisations: 19942002. SA-eDUC Journal 6(1): 33-57.

Ouma, G. W. 2007. Reducing resource dependence on government funding: The case of public universities in Kenya and South Africa. Unpublished doctoral dissertation. University of Cape Town.

Parker, D. 2015. What does "free education for all" really mean? https://www.dhet.gov.za/ SiteAssets/Latest\%20News/Independent\%20Thinking\%20Second\%20Edition/dhetpage3.pdf (Accessed 15 March 2017).

Pilane, P. 2016. Investigation into fee-free university education launched. https://mg.co.za/article/201601-20-investigation-into-fee-free-varsity-education-launched (Accessed 14 March 2016).

Phungo, R. 2015. University fees: Free higher education is possible in South Africa. https://www.dailymaverick.co.za/article/2015-10-21-university-fees-free-higher-education-ispossible-in-south-africa/\#.WRG5qOWGPcs (Accessed 3 September 2016).

Raborife, M. 2016. Fee-free universities would reduce quality of tertiary education, says CEO. http://www.news24.com/SouthAfrica/News/fee-free-universities-would-reduce-quality-oftertiary-education-says-ceo-20160413 (Accessed 3 April 2017).

SABC News. 2016. Free education for all not feasible: Manana. http://www.sabc.co.za/ news/a/cd65af004c50f448a2cdbe8be7d9f0df/Free-education-for-all-not-feasible:-Manana20160407 (Accessed 14 April 2016).

Singh, M. 2001. Reinserting the "public good" into higher education transformation. Kagisano Higher Education Discussion Series 1: 8-18. 
Smolentseva, A. 2015. Will there be free higher education in Russia? https://ejournals.bc.edu/ ojs/index.php/ihe/article/viewFile/7485/6680 (Accessed 3 September 2016).

Stuurman, S. 2016. Higher education not a basic right: Education Department. http://www.sabc.co.za/ news/a/a5e5b8004e7d132698509c5e4966ada6/Higher-education-n (Accessed 16 March 2016).

Teferra, D. 2016. Why free education is a folly in an unequal society. http://theconversation.com/whyfree-education-is-a-folly-in-an-unequal-society-54515 (Accessed 2 December 2016).

The Library of Congress. 2017. Constitutional right to an Education: South Africa. https://www.loc.gov/ law/help/constitutional-right-to-an-education/southafrica.php (Accessed 16 March 2017).

Vally, S., E. Motala, L. Naidoo, M. Hlatshwayo and R. Maharajh. 2016. Quality, free university education is necessary - and possible. https://mg.co.za/article/2016-01-28-quality-free-universityeducation-is-necessary-and-possible (Accessed 9 February 2016).

Vandenberghe, V. 2005. Free higher education. Regressive transfer or implicit loan? Discussion Paper 31. UC Louvain, Departement des Sciences Economiques.

Wangenge-Ouma, G. 2012. Tuition fees and the challenge of making higher education a popular commodity in South Africa. Higher Education 64(6): 831-844.

Wangenge-Ouma, G. and N. Cloete. 2008. Financing higher education in South Africa: Public funding, non-government revenue and tuition fees. South African Journal of Higher Education 22(4): 906919.

Wild, F. and A. Mbatha. 2015. Zuma says free university education is possible. http://www.fin24.com/ Economy/Zuma-says-free-university-education-is-possible-20151028 (Accessed 3 September 2016).

Wilson-Strydom, M. and S. N. Fongwa. 2012. A profile of higher education in Southern Africa. Volume 1: A Regional Perspective: 8-18.

Zusman, A. 2005. Challenges facing higher education in the twenty-first century. American Higher Education in the Twenty-first Century: Social, Political, and Economic Challenges 2: 115-160. 